\title{
INTRA-OPERATIVE ARTHROGRAPHY IN OPEN REDUCTION OF

\author{
CONGENITAL HIP DISLOCATION
}

\author{
DAN ATAR, ALFRED D. GRANT, WALLACE B. LEHMAN, ALLAN M. STRONGWATER
}

The use of an arthrogram in the pre-operative evaluation of congenital dislocation of the hip is well documented (Crawford and Carothers 1982), but its use after completing an open reduction is less well known. Usually,

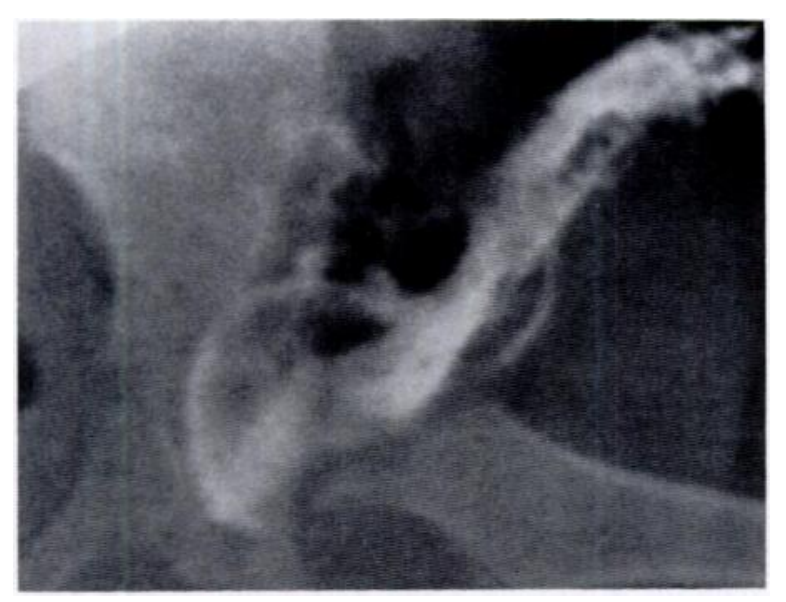

Fig. 1

D. Atar, MD, Chief, Paediatric Orthopaedic Surgery Soroka Hospital, Be'er Sheva, Israel.

A. D. Grant, MD, Director, Children's Orthopaedic and Arthritis Institute

W. B. Lehman, MD, Chief, Paediatric Orthopaedic Surgery

A. M. Strongwater, MD, Assistant Chief, Paediatric Orthopaedic Surgery

Hospital for Joint Diseases, Orthopaedic Institute, 30I East 17th Street, New York, New York 10003, USA.

Correspondence to Dr A. D. Grant.

(C) 1990 British Editorial Society of Bone and Joint Surgery $0301-620 \mathrm{X} / 90 / 3 \mathrm{R} 69 \$ 2.00$

J Bone Joint Surg [Br] 1990; 72-B: 526. the reduction is confirmed by an intra-operative roentgenogram. However, there are some cases in which the relationship between the femoral head and the acetabulum cannot be readily discerned from these films; either because the femoral head is not yet ossified, or because the films are not of sufficiently high quality. Lack of clarity may stem from poor radiological equipment, but sometimes it is due to osteoporosis resulting from prolonged traction (Sharrard 1971; Tachdjian 1972) or from immobilisation (Rose 1966; Pennock et al 1972; Uhthoff and Jaworski 1978).

To overcome these difficulties we use the following technique. First, we impregnate a piece of sterile gauze with $50 \%$ strength Hypaque solution, wrap this around the femoral head, and then reduce the head. The resultant arthrogram clearly demonstrates the relationship between the femoral head and the acetabulum (Fig. 1).

No benefits in any form have been received or will be received from a commercial party related directly or indirectly to the subject of this article.

\section{REFERENCES}

Crawford AH, Carothers TA. Hip arthrography in the skeletally immature. Clin Orthop 1982; 162:54-60.

Pennock JM, Kalu DN, Clark MB, Foster GV, Doyle FH. Hypoplasia of bone induced by immobilization. Br J Radiol 1972; 45:641-6.

Rose GA. Immobilization osteoporosis: a study of the extent, severity and treatment with bendrofluazide. Br J Surg 1966; 53:769-74.

Sharrard WJW. Paediatric Orthopaedics and Fractures. Oxford etc: Blackwell Scientific Publications, 1971.

Tachdjian MO. Pediatric orthopedics. Philadelphia etc: WB Saunders, 1972.

Uhthoff HK, Jaworski ZFG. Bone loss in response to long-term immobilisation. J Bone Joint Surg [Br] 1978; 60-B:420-9. 